\title{
Dividend Policy Decision across African Countries
}

\author{
Joseph Yensu $^{1} \&$ Charles Adusei $^{2}$ \\ ${ }^{1}$ Department of Entrepreneurship and Finance of Institute of Entrepreneurship and Enterprise Development, \\ Kumasi Polytechnic, Kumasi, Ghana \\ ${ }^{2}$ Department of Accounting, Finance and Banking Faculty of Business Studies Garden City University College, \\ Kumasi, Ghana \\ Correspondence: Joseph Yensu, Department of Entrepreneurship and Finance of Institute of Entrepreneurship \\ and Enterprise Development, Kumasi Polytechnic, Kumasi, Ghana. Tel: 233-0-505-604-383. E-mail: \\ joseph.yensu123@gmail.com
}

Received: February 29, 2016

Accepted: March 21, 2016

Online Published: May 25, 2016

doi:10.5539/ijef.v8n6p63

URL: http://dx.doi.org/10.5539/ijef.v8n6p63

\begin{abstract}
This paper provides analysis of the trends in dividend policy and differentials in firm and country specific factors for payers and non-payers of dividends and examines the predictions concerning the amount of dividends paid by listed non-financial firms in African countries. Using a panel dataset over the period 1994-2011 from 13 African countries, the study found that dividend payers are more profitable, have larger firm size, greater investment, higher retention of earnings and less financial leverage than non-paying firms. The results show that in countries where the GDP per capita is low, firms are more likely to pay dividends. The level of corruption is high for non-payers of dividends. The study also found a positive significant relationship between dividend payout, profitability, investment opportunities and firm size. However, a significant negative relationship was reported between dividend payout, financial leverage, corruption and gross domestic product per capita. The study further found that the dividend trends were very low and stable. The conclusion, therefore, indicates that although firm specific factors are important in Africa in determining dividend policy regarding payout, country specific factors play very significant roles in determining the dividend payout of African firms.
\end{abstract}

Keywords: dividend policy, trends, differentials, panel data, non- financial firms, Africa

\section{Introduction}

Baker, Veit and Powell (2001) define dividend policy as the payout policy that managers follow when deciding the size and pattern of cash distributions to shareholders over time. Miller and Modigliani (1961) argue that given perfect capital markets, the dividend decision does not affect firm value and is, therefore, irrelevant. However, subsequent studies have disproved the notion of a perfect capital market and have offered theories about how dividends affect firm value, and how managers should make dividend policy decisions (Baker et al., 2001). For instance, Dhanani (2005) outlined four types of market imperfections, thus rendering Miller and Modigliani's (1961) assertion untenable. Dhanani (2005) outlined these imperfections to be: constraints and conditions on capital availability and capital structure, information asymmetry between managers and shareholders, agency problems between managers and shareholders and, finally, differing shareholder circumstances (including different tax statuses).

Brealey and Myers ( 2005), described the issue of dividend policy as contentious, and, in fact, a puzzle. Dividend policy has been described by such researchers as Al-Kuwari (2009), Ahmed and Javid (2008), and Abor and Bokpin (2010) as one of the most intriguing topics in financial research. Al-Kuwari (2009) maintains that even though researchers have paid considerable attention to solving the dividend puzzle, this has resulted in a large number of conflicting hypotheses, theories and explanations. The current study seeks to examine the determinants of dividend payout and the differentials in firm and country specific factors for payers and non-payers of dividends. Secondly, it examines the predictions of the amount of dividends paid by listed non-financial firms in Africa taking into account both firm and country factors.

This study was motivated by the fact that most of the research about corporate dividends has been in advanced countries. With the exception of a few studies into corporate dividend payment in individual countries, such as Egypt, Ghana, Nigeria and South Africa, there has not been a single study of dividend payouts decisions in 
several African countries, also detailing the trends across a time period. This study therefore attempts to look at the issue of corporate dividend policy decision across 13 African countries, including Botswana, Ivory Coast, Egypt, Ghana, Kenya, Morocco, Namibia, Nigeria, South Africa, Tanzania, Uganda, Zambia and Zimbabwe. As the study also looks at the temporary effects (trends) of risks and shocks at specific times, it will therefore provide information for investors regarding the performance of firms in African countries over a period of time, and give a comprehensive understanding of how macro and micro factors impact on dividend policy decisions. The trends will again provide a clear direction for potential investors, and new entrants as well, and will go a long way to encourage firms and regulators in the individual countries to make decisions about dividend policies, especially when the relationships between the observed variables are taken into consideration. Furthermore, since most African countries have put in place measures to attract direct foreign investment and also encourage investors to invest in existing firms across Africa, this study will serve as basis for research into corporate dividend payout in the African context, which will enable investors to make informed decisions regarding their investments across Africa.

The contributions of this study are that it covers a longer time period (18 years), and include 13 African countries, which the researcher believes to be the first of its kind. It will therefore provide a conclusive statement from the findings. A further contribution of the study is that it takes into consideration country specific factors in addition to the firm factors, which broadens the limited scope of previously conducted research into dividend payout in individual countries. This study could be used as a stepping stone for future research to help in understanding or explaining in detail how the country specific factors contribute to dividend payout as countries continue to develop.

\section{Theoretical Overview of Dividend Policy}

Al-Malkawi, Rafferty, and Pillai (2010) have traced the background of dividend payout policy to the development of the corporate form itself. It was seen that the emergence of a dividend policy as being important to investors was, to some extent, driven by the evolving state of financial markets. Quoting from Frankfurter and Wood (2002), and Baskin (1987), Al-Malkawi et al. (2010), stated that investing in shares was initially seen as analogous to investing in bonds, so regularity of payments was important. It was also seen that in the absence of regular and accurate corporate reporting, dividends were often preferred to reinvested earnings, and often even regarded as a better indication of corporate performance than published earnings accounts. Several theories have been developed to explain dividend policy and these are discussed below.

The first of the theories is the Dividend Irrelevance theory propounded by Miller and Modigliani (1961). Basing their argument upon idealistic assumptions of a perfect capital market and rational investors, where there are no differences between taxes on dividends and capital gains, no transaction and flotation costs incurred when securities are traded, all market participants have free and equal access to the same information, no conflicts of interest between managers and security holders, and all participants in the market are price takers, Miller and Modigliani (1961) maintain that dividend policy is irrelevant. The theory explains that in a perfect market dividend policy has no effect on either the price of a firm's stock or its cost of capital. Shareholders' wealth is not affected by the dividend decision and therefore they would be indifferent about whether payment was in the form of dividends or capital gains. Miller and Modigliani (1961) s' main reason was that the wealth of the shareholder is affected by the income generated by the investment decisions made by the firm and not by how it distributes that income. Miller and Modigliani (1961) argued that regardless of how the firm distributes its income, its value is determined by its basic earning power and its investment decisions. Another theory that was propounded as a result of the fallout from the Miller and Modigliani (1961) Irrelevant theory is the Information Asymmetry Theory or the Signalling Theory.

Al-Malkawi et al. (2010) explain the Signalling hypothesis as what occurs when investors can infer information about a firm's future earnings through the signal coming from dividend announcements, both in terms of the stability of, and changes in, dividends. However, for this hypothesis to hold, managers should firstly possess private information about a firm's prospects, and have incentives to convey this information to the market. Secondly, a signal should be true: that is to say, a firm with poor future prospects should not be able to mimic and send false signals to the market by increasing dividend payments.

The main argument of the Agency Cost theory of dividend policy is that because of the imperfect nature of managers, some of whom might have interests which differ from that of the shareholders, they might engage in such activities as consuming excessive perquisites or over-investing in managerially rewarding, but unprofitable, activities. This may lead to high agency costs being incurred by the shareholders. According to this theory, the payment of dividends might serve to align the interests and mitigate the agency problems between managers and 
shareholders, by reducing the discretionary funds available to managers (Rozeff, 1982; Easterbrook, 1984; Jensen, 1986; Alli, Khan, \& Ramirez, 1993). Easterbrook (1984), and Lopez-Iturriaga and Crisostomo (2010) also argues in the same vein by maintaining that dividends could be used to reduce the free cash flow in the hands of managers and, in addition, oblige managers to approach the capital market to raise funds.

A further theory relating to dividend payments is the Clientele Effect theory. Because there is no perfect capital market, investors face different dividend and capital gains tax rates and they therefore have different after-tax valuations for the same asset. Miller and Modigliani (1961) hypothesized that such differences lead to the formation of what they termed "dividend clienteles", in which investors have tax-based preferences over equities that differ only in their dividend policies. According to Al-Malkawi et al. (2010) these clienteles will be attracted to firms that follow dividend policies that best suit their particular situations. Similarly, firms may tend to attract different clienteles by their dividend policies.

The Tax-effect hypothesis suggests that low dividend payout ratios lower the cost of capital and increase the stock price. In other words, low dividend payout ratios contribute to maximising a firm's value. According to Al-Malkawi et al. (2010), this argument is based on the assumption that dividends are taxed at higher rates than capital gains. In addition, dividends are taxed immediately, whereas taxes on capital gains are deferred until the stock is actually sold. These tax advantages of capital gains over dividends tend to predispose investors who have favourable tax treatment from capital gains to prefer companies that retain most of their earnings rather than pay them out as dividends and they (the investors) are willing to pay a premium for low-payout companies. Therefore, a low dividend payout ratio will lower the cost of equity and increase the stock price (Al-Malkawi et al., 2010).

Another theory offered to explain dividend policy decision is the 'Bird-in-the hand' theory. According to this theory, due to their imperfections and uncertainty, dividends are valued differently from retained earnings or capital gains. According to the theory, investors prefer the "Bird in the hand" of cash dividends rather than the "Two in the bush" of future capital gains (Al-Malkawi et al., 2010). Increasing dividend payments may then be associated with increases in firm value. As a higher current dividend reduces uncertainty about future cash flows, a high payout ratio will reduce the cost of capital, and hence increase share value. According to the so-called "Bird-in-the hand" hypothesis, high dividend payout ratios maximize a firm's value.

The last of the theories considered in this study is the Catering theory, which states that the propensity to pay dividends depends on a dividend premium (or sometimes discount) in stock prices. This theory was formulated by Baker and Wurgler (2004), as a way of relaxing the market efficiency as defence against Miller and Modigliani (1961)'s irrelevance theory. The essence of the Catering theory is that managers give investors what they currently want. In the case of dividends, catering implied that managers tended to initiate dividends when investors put a relatively high stock price on dividend payers, and tended to omit dividends when investors prefer non-payers.

\section{Empirical Evidence of Dividend Policy: Hypothesis Development}

\subsection{Investment Opportunities and Dividend Payout}

Abor and Bokpin (2010) maintain that investment opportunities available to a firm constitute an important component of market value, and that they affect the way the firm is viewed by managers, owners, investors, and creditors. Existing literature suggests a relationship between investment opportunities and dividend payout. In fact, Gul and Kealey (1999) found a negative relationship between growth options and dividends. Others support the fact that firms with higher market-to-book value tend to have good investment opportunities, and would retain more funds to finance such investment, thus recording lower dividend payout ratios (Rozeff, 1982). Empirical results obtained by Amidu and Abor (2006), Ahmed and Javid (2008), Al-Malkawi (2008) and Abor and Bokpin (2010) also found a negative relationship between investment opportunities and dividend policy. This study therefore hypothesizes that:

\section{Hypothesis 1: Investment opportunities are negatively related to dividend payout.}

\subsection{Profitability and Dividend Payout}

Profits have long been regarded as the primary indicator of a firm's capacity to pay dividends (Amidu \& Abor, 2006). Naceur, Goaied and Belanes, (2006), and Reddy and Rath (2005) found that highly profitable firms with more stable earnings can manage larger cash flows, and because of this they pay larger dividends. Ahmed and Javid (2008) also maintain that firms with fast growth distribute the larger dividends in order to attract investors. Empirical evidence also attests to these findings. For example, Dickens, Casey and Newman. (2002), Amidu and Abor (2006), Abor and Bokpin (2010), Al-Ajmi and Hussain (2011), Turen and Salman (2012), Al-Kuwari 
(2009) and Kim and Gu (2009) all found a statistically significant and positive relationship between profitability and the dividend payout ratio. Based on both theory and empirical evidence, the study hypothesizes that:

Hypothesis 2: There is a positive relationship between profitability and dividend payout.

\subsection{Firm Size and Dividend Payout}

It has been noted by Jensen, Solberg, and Zorn, (1992) and Fama and French (2001) that large firms distribute a higher amount of their net profits as cash dividends, than small firms do. Lloyd, Jahera, and Page (1985) considered size to be an important explanatory variable, and contended that large companies are more likely to increase their dividend payouts in order to decrease agency costs. Over the years, several studies have tested the impact of firm size on the dividend-agency relationship. Fama and French (2002), Al-Kuwari (2009), Al-Malkawi (2008), and Manos (2001) all found a positive relationship between firm size and dividend policy. However, Amidu and Abor (2006) and Ahmed and Javid (2008) found a negative relationship, meaning that large-sized firms prefer to pay a lesser dividend. This study, however, hypothesizes that:

\section{Hypothesis 3: There is a positive relationship between firm size and dividend.}

\subsection{Financial Leverage and Dividend Payout}

The level of financial leverage negatively affects the dividend policy of a firm. This has been confirmed by several studies (Crutchley \& Hansen, 1989; Jensen et al., 1992; Agrawal \& Jayaraman, 1994; Faccio \& Lang, 2002; Al-Malkawi, 2007). These studies made inference to the fact that highly levered firms look forward to maintaining their internal cash flow to fulfil duties, rather than distributing available cash to shareholders and protecting their creditors. The reason they adduced this was because highly levered firms carry a large burden of transaction costs from external financing and, in that case, firms need to maintain their internal source of funds to meet their duties, rather than distributing the available cash to shareholders as dividends. Also, Al-Kuwari (2009) found the leverage ratio to be strongly statistically significant and negatively associated with the dividend payout ratio. Based on the above empirical evidence, this study hypothesizes that:

Hypothesis 4: Financial leverage is negatively related with dividend payout.

\subsection{Country Specific Factors and Dividend Payout}

Literature regarding the relationship between gross domestic product per capita, corruption and dividend payout is very sparse and, according to the best knowledge of the researcher, this study is the first to consider national factors in addition to factors at the firm level in the context of Africa. In addition, this study included corruption levels as a governance indicator and gross domestic product per capita was used to measure economic development. A study by Peyton and Belasen (2012) indicated that corruption levels may increase in developing countries with regards to political freedom. This means corruption. could also affect levels of development negatively. This study hypothesizes that:

Hypothesis 5: Country level factors, such as gross domestic product per capital and corruption, impact negatively on dividend payout of firms across African countries.

\section{Data and Methodology}

\subsection{Methods and Construction of Variables}

The study employed panel data to identify the relationship between dividend payout (the dependent variable) and profitability, investment opportunity, financial leverage, firm size, tangibility of assets, corruption and gross domestic product per capita (independent variables) for the descriptive analysis. The selection of the variables used in this study was guided by previous studies. The dependent and independent variables were defined so as to be consistent with Fama and French (2002)'s, with some modifications in the analysis. The test attempted to explain the behaviour of dividend payout across firms and countries.

Following Fama and French (2002)'s approach, panel regression was developed to measure the impact of firm and country specific factors on a firm's corporate dividend policy decision. The first regression was based on the dividend payout of the firm specific variables assumed to determine dividend, and the second was based on country specific factors assumed to determine dividend. The third was based on the lag dependent value of the dividend payout by combining both the firm and country specific factors and also the application of a general method of moment to determine if the result of the lag model was unaffected by serial correlation. The general method of moments offers an efficient estimate of the dynamic model and is used to identify whether the lags used together with the parameters are not serially correlated, which will bias the findings by describing test statistics of the validity of the variables (Arellano \& Bond, 1991). 
The equation describes how corporate dividend payout varies across firms and countries as a function of the lagged dependent variable, profitability, investment opportunity, financial leverage, firm size, gross domestic product per capita and corruption. In the estimation of the models, the fixed effects on dividend payout were applied first. Secondly, the logarithms were used to transform the variables, thirdly, the lag values, and fourthly, the general method of moment (GMM) estimator was developed for the dynamic panel data. The GMM was further adopted to solve the problems of: (1) the presence of unobserved firm effects, and (2) the autoregressive process in the data (Gonzalez \& Gonzalez, 2012).The two tests suggested by Arellano and Bond (1991) were also used. The first was the Sargan and Hansen test of over-identifying restrictions. The model for the empirical examination of both firm and country specific factors for the firms across the selected African countries is therefore given as follows:

Equation 1: Firm factors

$$
D P Y 3_{i t}=\beta_{0}+\beta_{1}\left(D P Y 3_{-} \text {lag }\right)_{i t}+\beta_{2}(P R O F)_{i t}+\beta_{4}(I N V)_{i t}+\beta_{3}(F L E V)_{i t}+\beta_{4}(S I Z E)_{i t}+\varepsilon_{i t}
$$

Equation 2: Country factors

$$
D P Y 3_{i t}=\beta_{0}+\beta_{1}(C O R)_{i t}+\beta_{2}(\text { InGDPpercap })_{i t}+\varepsilon_{i t}
$$

Equation 3: Firm and country factors

$$
\begin{gathered}
D P Y 3_{i t}=\beta_{0}+\beta_{1}\left(D P Y 3_{-} \text {lag }\right)_{i t}+\beta_{2}(P R O F)_{i t}+\beta_{4}(I N V)_{i t}+\beta_{3}(F L E V)_{i t}+\beta_{4}(\text { SIZE })_{i t}+\beta_{6}(C O R)_{i t}+ \\
\beta_{7}(\text { InGDPpercap })_{i t}+\varepsilon_{i t}
\end{gathered}
$$

Where $i$ denotes an individual firm and $t$ representing the time dimension.

Table 1. Summary variables and definitions

\begin{tabular}{lll}
\hline Label & Variables & Definition \\
\hline DPY3 & Dividend policy & Dividend divide by total assets \\
DPY3_LAG & Lag Leverage & Lagged value of the dependent variable \\
PROF & Profitability & Earnings before tax and interest divided by total assets \\
FLEV & Financial leverage & Total debt divided by total assets \\
INV & Investment opportunity & Total market value of equity divided by total assets \\
SIZE & Firm size & Natural logarithm of assets \\
COR & Corruption & perception of the extent to which public power is exercised for private gain and others) \\
LnGDPPerca & Target Payout & Log of gross domestic product (GDP) \\
\hline
\end{tabular}

\subsection{Data Source and Sample}

The study used both firm- and country- level secondary data. The firm level secondary data was sourced from DataStream, Bloomberg and the stock exchanges of listed non-financial firms in African countries. Sample firms were selected from Botswana, Cote D'Ivoire, Egypt, Ghana, Kenya, Morocco, Namibia, Nigeria, South Africa, Tanzania, Uganda, Zambia and Zimbabwe during the eighteen year period, 1994-2011. These countries were selected because of data availability and the fact that the countries were mixed with middle and low income countries, high and low populations, war and non-war countries to provide a general and comprehensive understanding of how firms operate regarding their dividend policy decisions. In all, a total of 608 firms were sampled. The country specific factors were obtained from the World Bank development indicator and International Financial Statistics database of the International Monetary Fund during the period 1996-2011. These were necessary for accessing the governance indicators and the development indicators of the various countries in order to assess their impact on the dividend payouts of firms in Africa. The country specific factors included Gross Domestic Product per capita and corruption. Financial firms and utilities were not considered as their financial decisions are affected by different factors and rules undertaken by non-financial firms. This is supported by Gonzalez and Gonzalez (2012) and Wiwattanakantang (1999). 


\section{Empirical Results}

\subsection{Descriptive Statistics}

Table 2. Descriptive statistics of dividend payout decisions

\begin{tabular}{lccccc}
\hline Variable & Obs & Mean & Std. Dev. & Min & Max \\
\hline DPY3 & 5856 & 0.04 & 1.56 & 0 & 90.94 \\
ln_DPY3 & 4482 & -7.74 & 2.56 & -17.42 & 4.51 \\
PROF & 6668 & 0.10 & 0.25 & -13.69 & 1.37 \\
INV & 6035 & 1.54 & 9.35 & -0.46 & 491.26 \\
FLEV & 6800 & 0.17 & 0.18 & 0.00 & 3.26 \\
SIZE & 6901 & 4.97 & 2.10 & -3.37 & 22.68 \\
lnGDPperc & 10458 & 6.98 & 0.90 & 5.32 & 8.37 \\
COR & 7553 & -0.38 & 0.63 & -1.36 & 1.25 \\
\hline
\end{tabular}

The table shows the approximate average from the investigated variables across firms during the period 1994-2011

Table 2 above describes the descriptive statistics of the dependent and independent variables. It provides the mean, standard deviation of all the variables used in the study and the number of observations during the sample period. The mean value for dividend payout (dependent) is 0.04 , indicating that for the firms across the sample African countries selected for the study, the average dividend payout is 0.04 percent. However, but a variation in the dependent variable across the selected African countries during the period is provided by the standard deviation of 1.56, with a minimum and maximum dividend payout of 0.00 and 90.94 respectively. The mean investment opportunity is 1.54 , with a variation of 9.35 and minimum and maximum values of -0.46 and 491 respectively. All the countries have both positive and negative investment opportunities. Financial leverage has a mean value of 0.17 and a variation of 0.18 , with minimum and maximum values of 0.00 and 3.22 respectively. The profitability set has a mean value of 0.10 and a standard deviation of 0.25 , with minimum and maximum values of -13.69 and 1.37 respectively. Firm size has a mean value of 4.97 and a standard deviation of 2.10, with minimum and maximum values of -3.37 and 2.68 respectively. Gross Domestic Product per capita is measured as the log of GDP per capita and has a mean value of 6.98 and variation of 0.90 , with minimum and maximum values 5.32 and 8.37 respectively. Corruption shows a mean value of -0.38 and a standard deviation of 0.63 , with minimum and maximum values of -1.36 and 1.25 respectively.

Table 3. Trends in median dividend payout across African countries in the sample

\begin{tabular}{|c|c|c|c|c|c|c|c|c|c|c|c|c|c|c|c|c|c|c|}
\hline Country & 1994 & 1995 & 1996 & 1997 & 1998 & 1999 & 2000 & 2001 & 2002 & 2003 & 2004 & 2005 & 2006 & 2007 & 2008 & 2009 & 2010 & 2011 \\
\hline Botswana & - & 0.00 & 0.00 & 0.00 & 0.01 & 0.01 & 0.00 & 000 & 0.00 & 0.01 & 0.00 & 0.00 & 0.00 & 0.00 & 0.00 & 0.00 & 0.00 & 0.00 \\
\hline Egypt & - & - & 0.00 & 0.00 & 0.03 & 0.03 & 0.00 & 0.01 & 0.00 & 0.01 & 0.00 & 0.02 & 0.00 & 0.00 & 0.00 & 0.00 & 0.00 & 0.03 \\
\hline Ghana & - & 0.00 & 0.00 & 0.00 & 0.02 & 0.01 & 0.00 & 0.00 & 0.00 & 0.01 & 0.00 & 0.01 & 0.00 & 0.0 & 0.00 & 0.00 & 0.00 & 0.01 \\
\hline Ivory $\mathrm{C}$ & - & - & - & - & 0.02 & 0.06 & 0.02 & 0.04 & 0.02 & 0.01 & 0.02 & 0.05 & 0.03 & 0.01 & 0.04 & 0.01 & 0.01 & 0.01 \\
\hline Kenya & - & - & - & 0.00 & 0.03 & 0.00 & 0.00 & 0.00 & 0.00 & 0.00 & 0.00 & 0.02 & 0.03 & 0.00 & 0.03 & 0.00 & 0.00 & 0.00 \\
\hline Morocco & 0.00 & 0.00 & 0.01 & 0.01 & 0.01 & 0.02 & 0.01 & 0.02 & 0.01 & 0.01 & 0.01 & 0.01 & 0.00 & 0.01 & 0.01 & 0.01 & 0.01 & 0.00 \\
\hline Nigeria & - & - & - & 0.00 & 0.00 & 0.00 & 0.00 & 0.00 & 0.01 & 0.00 & 0.00 & 0.00 & 0.01 & 0.00 & 0.00 & 0.00 & 0.00 & 0.00 \\
\hline South A & 0.00 & 0.00 & 0.00 & 0.00 & 0.00 & 0.00 & 0.00 & 0.00 & 0.03 & 0.00 & 0.02 & 0.00 & 0.00 & 0.00 & 0.00 & 0.00 & 0.00 & 0.00 \\
\hline Tanzania & - & - & - & - & & 0.00 & 0.00 & 0.00 & 0.01 & 0.00 & 0.0 & 0.01 & 0.01 & 0.00 & 0.00 & 0.00 & 0.01 & 0.00 \\
\hline Tunisia & - & - & - & 0.01 & 0.00 & 0.01 & 0.01 & 0.00 & 0.00 & 0.00 & 0.01 & 0.01 & 0.04 & 0.00 & 0.00 & 0.00 & 0.01 & 0.03 \\
\hline Uganda & - & - & - & 0.00 & 0.00 & 0.01 & 0.00 & 0.00 & 0.00 & 0.00 & 0.00 & 0.00 & 0.00 & 0.00 & 0.00 & 0.00 & 0.01 & 0.00 \\
\hline Zambia & 0.00 & 0.00 & 0.00 & 0.00 & 0.00 & 0.00 & 0.00 & 0.00 & 0.00 & 0.00 & 0.00 & 0.00 & 0.00 & 0.00 & 0.00 & 0.00 & 0.01 & 0.00 \\
\hline Zimbabwe & 0.00 & 0.00 & 0.00 & 0.00 & 0.00 & 0.01 & 0.00 & 0.00 & 0.00 & 0.02 & 0.01 & 0.03 & 0.03 & 0.00 & 0.00 & 0.00 & 0.02 & 0.00 \\
\hline
\end{tabular}

Ivory $\mathrm{C}$ and South A denotes Ivory Coast and South Africa respectively. This table shows the annual trends in median dividen payout across across in the sample. The sample estimates are in percentage and full sample period is 1994 to 2011.

From Table 3 above, the dividend payout ratios from the selected African countries were very low and stable between 1994-2011. All the countries have a dividend payout ranging from 0 to 0.04 . The general pattern of dividend payouts across all the countries under study provides a very low and stable dividend payout for all the countries. 
One reason for the low and stable dividend payout policy decision is the fact that agencies monitoring the supply of capital, and correct cash flow for companies are controlled by organisations not under government control, and therefore not properly managed, which again leads to high cost of capital and keeping money for selfish interests, thereby making it impossible for firms to pay high dividend payments to shareholders (Jensen \& Meckling, 1976). Another reason suggested by Chazi, Terra, and Zanella (2010), Myers and Majluf (1984) and Miller and Rock (1985) is that high financial burdens are faced by firms in Africa, and consequently they prefer to finance a firm's expansion with their low profit margin and retaining earnings which may affect their capability to pay high dividends. Naceur et al. (2006) mentioned that that low and stable dividend payout policy in Africa could mean that the firms are not expanding very fast to facilitate high retain earnings to support shareholders, since the available money is used for firm's growth opportunities. Evbayowieru (2011) p. 62 stated that "capital gain seekers welcome low dividend payout policy because of low taxation" and scrip issue benefits". This could be the case in these selected African countries.

Table 4. Differentials of payers and non-payers of dividend across the countries

\begin{tabular}{|c|c|c|c|c|c|}
\hline COUNTRY & PROF & INV & FLEV & SIZE & RE \\
\hline \multicolumn{6}{|c|}{ BOTSWANA } \\
\hline Nonpayers & 0.07 & 1.45 & 0.00 & 2.68 & 0.24 \\
\hline Payers & 0.14 & 1.13 & 0.06 & 3.12 & 0.84 \\
\hline \multicolumn{6}{|l|}{ EGYPT } \\
\hline Nonpayers & 0.04 & 0.86 & 0.23 & 4.89 & 0.32 \\
\hline Payers & 0.09 & 0.82 & 0.13 & 4.76 & 0.50 \\
\hline \multicolumn{6}{|l|}{ GHANA } \\
\hline Nonpayers & 0.01 & 1.08 & 0.21 & 2.32 & 0.39 \\
\hline Payers & 0.09 & 0.93 & 0.14 & 3.43 & 0.53 \\
\hline \multicolumn{6}{|c|}{ IVORY_COAST } \\
\hline Nonpayers & 0.02 & 0.65 & 0.25 & 3.88 & 0.28 \\
\hline Payers & 0.10 & 0.69 & 0.11 & 4.54 & 0.6 \\
\hline \multicolumn{6}{|l|}{ KENYA } \\
\hline Nonpayers & 0.04 & 0.73 & 0.28 & 3.01 & 0.72 \\
\hline Payers & 0.09 & 0.91 & 0.07 & 4.03 & 0.81 \\
\hline \multicolumn{6}{|l|}{ MOROCCO } \\
\hline Nonpayers & 0.05 & 0.94 & 0.28 & 4.13 & 0.28 \\
\hline payers & 0.10 & 1.15 & 0.12 & 4.43 & 0.54 \\
\hline \multicolumn{6}{|l|}{ NIGERIA } \\
\hline Nonpayers & 0.00 & 0.70 & 0.18 & 2.83 & 0.66 \\
\hline Payers & 0.122 & 1.08 & 0.06 & 4.08 & 0.70 \\
\hline \multicolumn{6}{|c|}{ SOUTH_AFRICA } \\
\hline Nonpayers & 0.08 & 0.91 & 0.19 & 5.92 & 0.51 \\
\hline Payers & 0.13 & 1.15 & 0.12 & 6.26 & 0.75 \\
\hline \multicolumn{6}{|l|}{ TANZANIA } \\
\hline Nonpayers & & & & - & \\
\hline Payers & 0.26 & 2.21 & 0.05 & 5.30 & 0.84 \\
\hline \multicolumn{6}{|l|}{ TUNISIA } \\
\hline Nonpayers & 0.02 & 0.77 & 0.27 & 4.01 & 0.43 \\
\hline Payers & 0.08 & 0.88 & 0.14 & 3.69 & 0.51 \\
\hline \multicolumn{6}{|l|}{ UGANDA } \\
\hline Nonpayers & 0.03 & 0.96 & 0.16 & 4.67 & 0.88 \\
\hline Payers & 0.14 & 0.89 & 0.04 & 4.67 & 4.76 \\
\hline \multicolumn{6}{|l|}{ ZAMBIA } \\
\hline Nonpayers & 0.11 & 0.98 & 0.31 & 4.59 & 0.90 \\
\hline Payers & 0.16 & 0.92 & 0.08 & & 0.96 \\
\hline \multicolumn{6}{|c|}{ ZIMBABWE } \\
\hline Nonpayers & 0.02 & 1.02 & 0.07 & 4.44 & 0.89 \\
\hline Payers & 0.18 & 1.46 & 0.07 & 6.01 & 0.97 \\
\hline
\end{tabular}

This table shows the summary differentials of payers and non-payers of dividend across the countries in the sample from 1994-2011. Sample estimates are in percentage. 
Table 4 above describes the median values of the differentials of payers and non-payers of dividend. Profitability (PROF) is defined as the ratio of earnings before interest and tax to the book value of total assets. Investment opportunities (INV) are measured as the total market value of equity divided by the total assets. Financial leverage (FLEV) is measured as the total debt to total assets. Firm size (SIZE) is measured as the natural log of total assets. Retained earnings (RE) are measured as the ratio of retained earnings to total equity.

Consistent with Fama and French (2001), Denis and Osobov (2008) and Reddy and Rath (2005) firms across the countries indicated that payers of dividends tended to have more profit margins and a larger firm size, with only Tunisia and Zambia having smaller firm sizes. Firm size was not homogenous across all countries, but it appeared that larger firms tended to pay more dividends. This is an indication that payers and non-payers of dividends differ in terms of firm size.

The association established between dividend payments and investment opportunities was not the same across the countries. Botswana, Egypt, Ghana, Uganda and Zambia had lower values for investment opportunities. Ivory Coast, Kenya, Morocco, Nigeria, South Africa, Tunisia and Zimbabwe had higher values for investment opportunities. Looking at the investment outcome, it can be considered that payers of dividends tended to have higher values for investments. The results are consistent with the findings by La Porta, Lopez-DeSilanes, Shleifer and Vishny, (2000), cited in Denis and Osobov (2008). It was also found that dividend payers had higher retained earnings than non-paying dividend firms, which is in line with findings by Denis and Osobov (2008). A payer of dividends tended to have low financial leverage, whilst non-payers tended to have more leverage across the selected countries, with the exception of Botswana, which had lower leverage.

Table 5. Median differentials values of payers and non-payers of dividend payout across firms 1994-2011

\begin{tabular}{lccccccccccccccccccccc}
\hline Variables & 1994 & 1995 & 1996 & 1997 & 1998 & 1999 & 2000 & 2001 & 2002 & 2003 & 2004 & 2005 & 2006 & 2007 & 2008 & 2009 & 2010 & 2011 \\
\hline PROF & & & & & & & & & & & & & & & & & & & \\
Non Payers & 0.04 & 0.04 & 0.04 & 0.04 & 0.04 & 0.04 & 0.05 & 0.05 & 0.06 & 0.04 & 0.03 & 0.04 & 0.04 & 0.03 & 0.05 & 0.04 & 0.02 & 0.03 \\
Payers & 0.12 & 0.12 & 0.13 & 0.11 & 0.12 & 0.12 & 0.11 & 0.11 & 0.11 & 0.11 & 0.12 & 0.12 & 0.13 & 0.13 & 0.14 & 0.11 & 0.12 & 0.11 \\
INV & & & & & & & & & & & & & & & & & & \\
Non Payers & 2.24 & 1.29 & 1.54 & 0.83 & 0.89 & 0.69 & 0.74 & 0.73 & 0.72 & 0.77 & 0.92 & 0.99 & 1.16 & 1.16 & 1.06 & 0.98 & 0.81 & 0.85 \\
Payers & 1.11 & 1.12 & 1.15 & 1.21 & 1.04 & 0.94 & 0.89 & 0.76 & 0.72 & 0.82 & 0.95 & 1.09 & 1.23 & 1.53 & 1.25 & 1.11 & 1.20 & 1.02 \\
FLEV & & & & & & & & & & & & & & & & & & \\
Non Payers & 0.23 & 0.21 & 0.15 & 0.13 & 0.15 & 0.23 & 0.24 & 0.25 & 0.28 & 0.27 & 0.22 & 0.13 & 0.19 & 0.15 & 0.11 & 0.16 & 0.18 & 0.13 \\
Payers & 0.09 & 0.09 & 0.09 & 0.11 & 0.10 & 0.12 & 0.11 & 0.12 & 0.11 & 0.11 & 0.11 & 0.11 & 0.11 & 0.12 & 0.13 & 0.13 & 0.11 & 0.11 \\
SIZE & & & & & & & & & & & & & & & & & \\
Non Payers & 5.09 & 3.28 & 4.26 & 4.58 & 4.23 & 4.17 & 3.99 & 4.15 & 4.42 & 4.03 & 3.61 & 3.71 & 4.09 & 4.24 & 4.42 & 4.52 & 4.41 & 4.46 \\
Payers & 5.32 & 5.39 & 5.12 & 5.19 & 5.02 & 4.90 & 4.83 & 4.73 & 4.70 & 4.97 & 4.86 & 4.95 & 4.97 & 5.17 & 5.23 & 5.14 & 5.39 & 5.54 \\
COR & & & & & & & & & & & & & & & & & & \\
Non Payers & -0.76 & -0.65 & -0.03 & -0.29 & -0.47 & -0.23 & -0.52 & -0.66 & -0.57 & -0.71 & -0.31 & -0.56 & -0.26 & - & - & - & - & - \\
Payers & -0.07 & -0.25 & -0.39 & -0.29 & -0.47 & -0.54 & -0.52 & -0.66 & -0.67 & -0.71 & -0.43 & -0.56 & -0.68 & - & - & - & - & - \\
lnGDPper & & & & & & & & & & & & & & & & & \\
Non Payers & 7.98 & 7.99 & 8.01 & 8.02 & 7.99 & 7.99 & 7.29 & 7.31 & 7.32 & 7.33 & 7.32 & 6.09 & 7.39 & 7.45 & 7.53 & 7.56 & 7.52 & 7.55 \\
Payers & 7.10 & 7.03 & 7.13 & 7.09 & 7.15 & 7.15 & 7.15 & 7.21 & 7.23 & 7.28 & 7.32 & 7.33 & 7.39 & 7.41 & 7.46 & 7.49 & 7.52 & 7.55 \\
\hline
\end{tabular}

Table 5 above describes the time trends of both payers and non-payers of dividends. Over the time period of the study, dividend payers have a higher level of profitability, ranging from 0.11 to 0.13 , than non-payers of dividends, which ranged between 0.03 to 0.06 . Investment opportunities differed across both payers and non-payers of dividends, but it appears that payers of dividends tended to have more investment opportunities than non-payers. The range for payers was 0.82 to 1.53 and for non-payers 0.73 to 2.24 across the years respectively. Financial leverage showed that non-payers of dividends had high-level leverage, ranging from 0.13 to 0.28 , whilst payers had low level leverage, ranging from 0.10 to 0.13 over the timespan. With firm size, dividends payers were larger organisations than non-payers. The range was between 4 to 6 and 3 to 5 respectively. The findings are in line with Fama and French (2001). Payers of dividends had less gross domestic product per capita and lower levels corruption, whilst non-payers had high-levels respectively. 


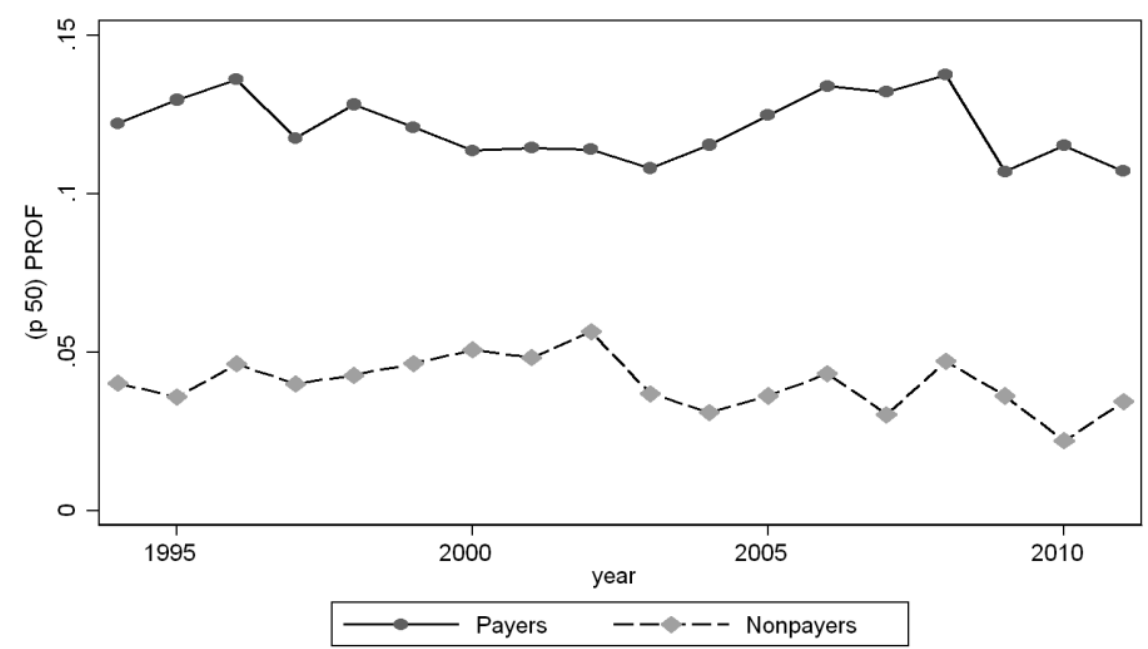

Figure 1. Differentials in median profitability of payers and non- payers across firms, 1994-2011 Source: Bloomberg.

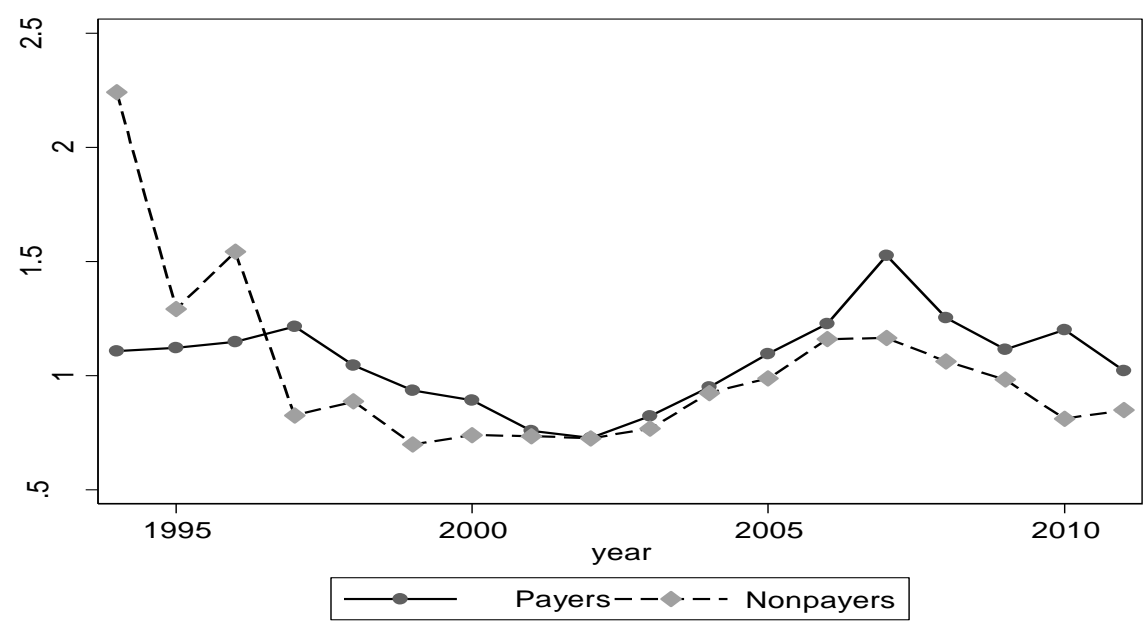

Figure 2. Differentials in median investment for payers and non-payers across firms, 1994-2011 Source: Bloomberg.

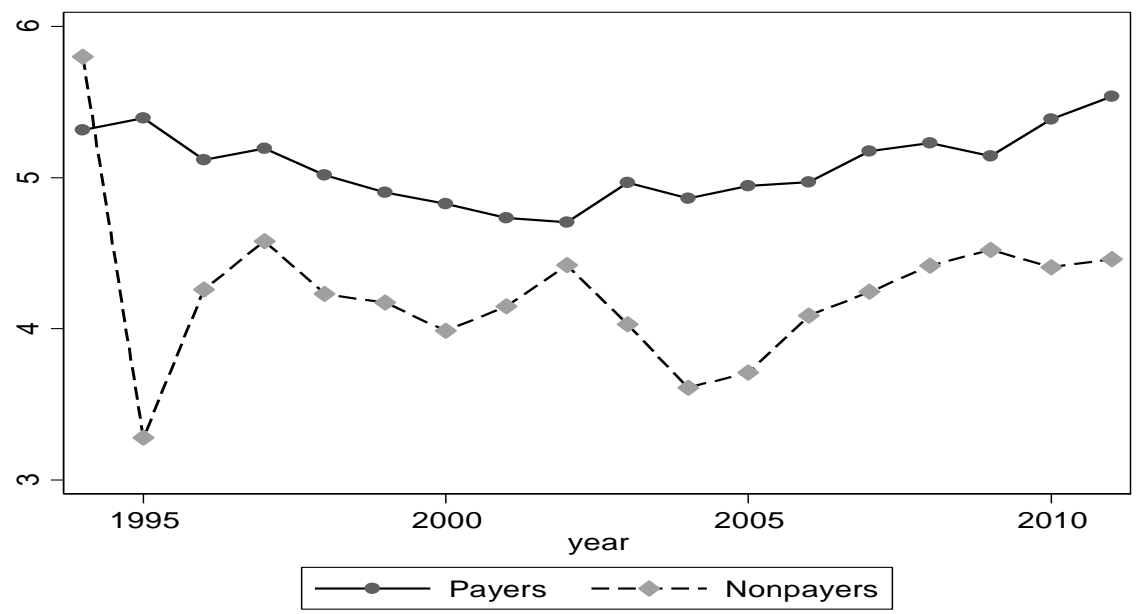

Figure 3. Differentials in median firm size of payers and non-payers across firms, 1994-2011 Source: Bloomberg. 


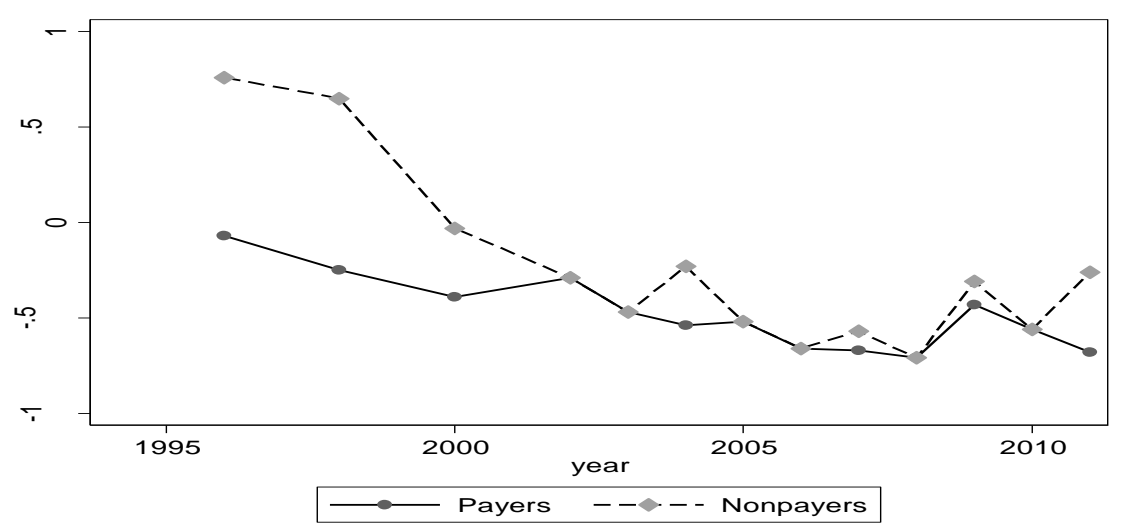

Figure 4. Differentials in median corruption of payers and non-payers across firms, 1994-2011

Source: World Bank Development database.

Table 6. Pair wise correlation matrix coefficient between selected variables

\begin{tabular}{|c|c|c|c|c|c|c|c|c|c|}
\hline Variables & DPY3 & PROF & INV & FLEV & SIZE & $\operatorname{lnGDP}$ & COR & GDP & ROL \\
\hline DPY3 & 1.00 & & & & & & & & \\
\hline PROF & 0.01 & 1.00 & & & & & & & \\
\hline INV & $0.86^{*}$ & $0.04 *$ & 1.00 & & & & & & \\
\hline FLEV & -0.01 & $-0.08 *$ & 0.01 & 1.00 & & & & & \\
\hline SIZE & $-0.06^{*}$ & $0.17^{*}$ & $-0.10^{*}$ & $0.07 *$ & 1.00 & & & & \\
\hline InGDPPc & -0.00 & $0.03^{*}$ & -0.02 & -0.01 & $0.36^{*}$ & 1.00 & & & \\
\hline COR & -0.00 & $0.04 *$ & $-0.03 *$ & $0.03^{*}$ & $0.30 *$ & $0.80^{*}$ & 1.00 & & \\
\hline GDPcons & $-0.03 *$ & $0.10^{*}$ & $-0.03 *$ & -0.00 & $0.44^{*}$ & $0.68^{*}$ & $0.38 *$ & 1.00 & \\
\hline RoL & -0.01 & $0.03^{*}$ & $-0.05^{*}$ & -0.00 & $0.28 *$ & $0.80^{*}$ & 0.88 & $0.42 *$ & 1.00 \\
\hline
\end{tabular}

Source: Datastream, World Bank Development Indicators and Bloomberg. Pair wise correlation coefficient estimated on a sample during the period 1994-2011.* indicates significance

\subsection{Regression Analysis}

Table 7. Summary results of fixed effects, lag and general method of moments

\begin{tabular}{|c|c|c|c|c|c|c|}
\hline Variable & FE (1) & FE.(2) & FE.(3) & FE. $\log (4)$ & FE $\operatorname{lag}(5)$ & $\operatorname{GMM}(6)$ \\
\hline \multicolumn{7}{|l|}{ DPY3 } \\
\hline Lag_DPY3 & - & - & - & - & $0.02 * * *$ & -0.08 \\
\hline PROF & $0.25^{* * * *}$ & $0.24 * * *$ & - & -0.13 & $-0.20 * * *$ & 0.01 \\
\hline INV & $0.09 * * *$ & $0.09 * * *$ & - & $0.09 * * *$ & $0.09 * * *$ & -0.01 \\
\hline FLEV & - & $-0.01 *$ & - & $-0.17 * * *$ & $-0.14 * * *$ & -0.02 \\
\hline SIZE & - & -0.01 & - & 0.02 & $0.04 * * *$ & -0.01 \\
\hline COR & - & - & $-0.29 * *$ & $-0.07 *$ & $-0.04 * *$ & 0.01 \\
\hline $\operatorname{lnGDPPc}$ & - & - & -0.06 & $-0.22 * *$ & $-0.28 * * *$ & 0.01 \\
\hline Constant & $-0.15^{* * * *}$ & $-0.13 * * *$ & 0.53 & 0.42 & $1.81^{* * *}$ & \\
\hline No. of obser & 5208 & 5165 & 4581 & - & 3605 & - \\
\hline \multicolumn{7}{|l|}{ R-squared: } \\
\hline within & 0.78 & 0.78 & 0.00 & - & 0.92 & - \\
\hline Between & 0.60 & 0.60 & 0.00 & - & 0.89 & - \\
\hline Overall & 0.75 & 0.75 & 0.00 & - & 0.85 & - \\
\hline AR (1) & - & - & - & - & - & 0.18 \\
\hline $\mathrm{AR}(1)$ & - & - & - & - & - & 0.54 \\
\hline Sargan test & - & - & - & - & - & 0.00 \\
\hline Hansen test & - & - & - & - & - & 0.07 \\
\hline
\end{tabular}

This table presents a summary of the regression results for both the firm and country specific factors using data from 1994-2011. The dependent variable is the dividend policy (DPY3) and.the superscripts ***,*** denote significances at 1 percent, 5 percent, and 10 percent level, respectively. The Sargan and Hansen test confirmed the absence of an exogeneity problem. The p-value for the second order serial correlation was insignificant, indicating no serial correlation. 
From the above, Model 5 was considered to be the most appropriate model because it explains $85 \%$ of the dividend payout. The model represents the lag value of dividend payout, which has a higher percentage than the other models. The lag value of dividend payout was applied to eliminate all serial correlation, and was tested by applying the general method of moment model. The Sargan and Hansen test confirmed the absence of an exogeneity problem. With regard to the hypothesis of second-order serial correlation, the study failed to reject the null hypothesis of no autocorrelation, since the p-value was insignificant.

From Table 7, the estimated coefficient of the lagged dividend payout was positive $(0.02)$ and statistically significant at a level of $1 \%$ for firms in Africa using the lag model, with an $R^{2}$ of $0.85 \%$. The coefficient therefore gives a direct relationship between the lag dividend and dividend payout, which implies that an increased in the lag dependent produced a significant positive effect on dividend payment. The economic significance is that the value of the coefficient indicated that, with a change of $1 \%$ in previous firms' dividend payout policy, there will be a corresponding change of $2 \%$ on the current year dividend payment, when all the other factors are fixed. In absolute terms, the size of the coefficient value (0.02) was very small, implying that changes in the lag dividend yielded a smaller effect on the current dividend. The result is consistent empirically with findings for which similar variation is observed in the literature, including Turen and Salman (2012) and Al-Ajmi and Hussain (2011). It indicates that the current dividend payment has an impact on the previous year dividend in African countries.

From Table 7 Models 1, 2, \& 5 provide the regression results, with dividend payout as the dependent variable. As indicated in the tables, the coefficient of profitability was $0.25,0.24,-0.20$ with significance levels of $1 \%, 1 \%$ and $1 \%$ respectively, although it was surprising to see that the signs of the coefficient were mixed, being both statistically positive and negative significant. The only difference was that when country factors were added to the regression the coefficient of the profitability tended to be negative, which again was quite surprising. The positive significance coefficient of the profitability provided support for Hypothesis 2, which means that an increase in profitability will lead to a rise in the dividend payment by firms in Africa. The economic significance of the evidence provided that a $1 \%$ rise in profitability when only firm factors are considered will increase the dividend payment by $25 . \%$, all other things being equal. Theoretically, the positive significant result provided evidence which is consistent with this study's predictions of a positive relationship between profitability and dividend payout and supports other research findings, such as Fama and French (2002), Al-Kuwari (2009) and Al-Malkawi (2008), who maintain that firms with less investment but high profit are more likely to pay high dividends. The results also support the findings of Abor and Bokpin (2010), who emphasised that highly profitable firms are more likely to pay dividends to their shareholders. However, with the introduction of country specific factors into the regression, the coefficient of profitability changed to negative $(-0.20)$ with the same significance levels, implying that firms with profit will have fewer dividend payout policies, which rejected this study's prediction of a positive relationship between profitability and dividend payout when country factors are run together with firm factors. Empirically, the negative findings are in line with the suggestion by Abor and Bokpin (2010) that firms with high profits tend to pay lower dividends, as they may keep their retained earnings in order to finance future growth and investment opportunities. Another reason for this situation could be attributed to corruption levels in African countries. In countries where corruption is high, highly profitable firms could be retaining their profits to pay their way through in situations where there are poor governance practices.

From Table 7 Models 1, 2 and 5, the results of the regression analysis for the investment opportunities variable produced a similar positive coefficient of 0.098, 0.09 and 0.09, all at significant levels of $1 \%$ in all the models, implying that high investment opportunities in African countries would have more impact on dividend payments. The economic significance is that a $1 \%$ rise in investment opportunities will increase dividend payout policies of firms by $9 . \%$, when all other factors are fixed. In absolute terms the coefficient value has less impact on dividend payout. Theoretically, the positive significant relationship between investment opportunities and dividend payout signified that an increase in investment increases the dividend payout. The positive result rejects Hypothesis 1 of a negative relationship between investment opportunities and dividend payout, but is consistent with the study of Fama and French (2002), who argue that firms with more investments tend to have lower dividend payouts in the long term. However, the result is not in line with the findings by Abor and Bokpin (2010), Amidu and Abor (2006), Ahmed and Javid (2008) and Al-Malkawi (2008).

The regression analysis from Table 7 Models 1, 2, and 5, showed that financial leverage produced negative coefficients of $-0.01,-0.17,-0.14$ at significant levels of $10 \%, 1 \%$ and $1 \%$ respectively, meaning that firms in African countries with high leverage will lead have a significant reduction in dividend payout. The economic significance is that a $1 \%$ increase in firm's financial leverage will lead to $14 . \%$ decrease in a firm's dividend payout policy, holding all other factors constant. The impact of the financial leverage on dividend policy decision is very 
high, since the magnitude of the absolute value of the coefficient is large. Theoretically, the result, showing a strong negative relationship, supports this study's predictions of a negative relationship between financial leverage and dividend payout (Hypothesis 4). The result is in line with previous studies by Jensen et al. (1992) and Al-Malkawi (2007). They maintained that highly levered firms look forward to maintaining their internal cash flow to fulfil duties, rather than distributing available cash to shareholders and protecting their creditors. Fama and French (2002) and Al-Kuwari (2009) also found a negative relationship between leverage and dividend payout. The results confirm previous studies and support the hypothesis.

In this study, the regression result for firm size, indicated in Table 7 Model 5, showed a coefficient of 0.04 at a significant level of $1 \%$ using the lag model. The established relationship demonstrated a statistically significant direct relationship between firm size and dividend payout, which strongly provided theoretical support for Hypothesis 3, of a positive relationship between firm size and dividend payout, suggesting that diversifications of firms will lead to high dividend payout. The economic implication means that a $1 \%$ increase in the size of the firm will be associated with $4 \%$ rise in the dividend payout, when all other factors are fixed. Theoretically, the result is consistent with, and also confirms, the findings of Fama and French (2002), Al-Kuwari (2009), Al-Malkawi (2008), Manos (2001) and Jensen et al. (1992), who emphasized that large firms distribute a higher amount of their net profits as cash dividends, than do small firms. The results, however, are not in line with the studies of Amidu and Abor (2006), and Ahmed and Javid (2008), who found a negative relationship..

For the governance issue of corruption, the results of the regression from Table 7 Models 3 and 5 indicated negative coefficients of $-0.29,-0.04$ at significant levels of 5\%, and 5\% respectively, which supported Hypothesis 5, of a negative relationship between corruption level and dividend payout, and indicated that African countries with high levels of corruption will impact inversely on dividend payment. The economic implication of the absolute coefficient value was that a $1 \%$ rise in the governance indicator (corruption) will lead to $4 \%$ decrease in dividend payout in African countries, holding all other factors constant. The magnitude of the coefficient shows that corruption has a larger impact on dividend payment. The results indicated that firm's experiencing high corruption tend to have low dividend payout. This means that the corruption, as a vector for government indicators, did affect the dividend payouts of firms in Africa. This may imply that corruption levels in African countries affected the firms' ability to pay dividends, hence, the higher the corruption level, the lower the dividend payout. The findings support the hypothesis established.

The results of the regression analysis gave a negative significant relationship between dividend payout and Gross Domestic Product per capita, with coefficients of $-0.22,-0.28$ at significant levels of 5\%, and $1 \%$ respectively, indicating that the higher the GDP per capita, the lower the dividend payout. The economic significance suggested that a $1 \%$ increase in GDP per capita will induce a $28 \%$ fall in dividend payout, all other things being constant. The absolute coefficient demonstrated that GDP per capita impacted strongly on dividend payout when compared with the firm factors. This finding contradicts that of Abor and Bokpin (2010), who found no established relationship. The negative significance implies that in a country where GDP per capita is high, shareholders are less likely to consider or expect dividend payments.

\section{Conclusion and Implications}

This study examined the trends in dividend payout and differentials in firm and country level specific factors for payers and non-payers of dividends. The study also examined the predictions of the amount of dividends paid by listed non-financial firms in Africa.The study found that dividend payers were more profitable, had larger firm size, more investment, high retaining earnings and less financial leverage than non-paying firms. The findings also show that in countries where GDP per capita is low, firms were more likely to pay dividends. Corruption was highly associated with non-payers of dividends.

The study also found a positive relationship between dividend payout and investment opportunities, firm size and lagged of dividend. However, negative relationships were identified between dividend payout and financial leverage, profitability, corruption and gross domestic product per capita. Profitability was positive and significant when only firm factors were regressed, but became negative when both firm and country factors were regressed together. The lag dividend payout, profitability, investment opportunities, financial leverage, firm size, corruption and Gross Domestic Product per capita were the significant determinants of dividend payout in these selected African countries at levels of $1 \%, 5 \%$ and $10 \%$. The findings indicated that the hypotheses or the predictions stated are applicable and explained dividend policy decisions in the context of African countries.

In conclusion, dividend payout in the selected Africa countries was stable across the time period under study. The study also concluded that dividend payout is affected by firm and country specific factors, and that the results of the findings are consistent with the literature about firm specific factors. 
The implications of dividend policy have been discussed in relation to the development of the stock market of a country. According to the Bird-in-hand hypothesis of dividend policy, firms that pay high dividends increase stock value (Al-Malkawi et al., 2010). That is to say, according to the so called "Bird-in-the hand" hypothesis, high dividend payout ratios maximize a firm's value. Studies that provide support for the "Bird-in-the hand" include Gordon and Shapiro (1956) and Lintner (1956). Fisher (1961) also used data from Britain for the period between 1949 and 1957 to conclude that dividends have greater impact on share prices than retained earnings.

It is also a known and established fact that stock markets are important source of finance for funding corporate growth and relate positively to economic development of any country (Antonios, 2010; Yartey, 2009). For example, according to Pagano (1993), stock markets contribute to the mobilization of domestic savings by enhancing the set of financial instruments available to savers to diversify their portfolios, providing an important source of investment capital at relatively low cost. He maintains that a well-functioning and liquid stock market, that allows investors to diversify away from unsystematic risk, will increase the marginal productivity of capital (Pagano, 1993). Antonios (2010) argues that rising share prices tend to be associated with increased business investment and vice versa and, also, share prices also affect the wealth of households and their consumption. Higher household consumption also engenders economic growth, if the consumption is of locally produced commodities. Furthermore, the evolution of stock markets, according to Khan and Sendahji (2000), has an impact on the operation of banking institutions and, hence, on economic promotion. This means that stock markets are becoming more crucial, especially in a number of emerging markets and their role should not be ignored (Khan \& Sendahji, 2000). Levine and Zervos (1998) argued that a well-established stock market not only can mobilize capital and diversify risks between market agents, but it is also able to provide different types of financial services than the banking sector to stimulate economic growth.

\section{References}

Abor, J., \& Bokpin, G. A. (2010). Investment Opportunities, Corporate Finance, and Dividend Payout Policy: Evidence from Emerging Markets. Studies in Economics and Finance, 27(3), 180-194. http://dx.doi.org/10.1108/10867371011060018

Agrawal, A., \& Jayaraman, N. (1994). The Dividend Policies of all-Equity Firms: A Direct Test of the Free Cash Flow Theory. Managerial and Decision Economics, 15, 139-148. http://dx.doi.org/10.1002/mde.4090150206

Ahmed, H., \& Javid, A. Y. (2008). Dynamics and Determinants of Dividend Policy in Pakistan: Evidence from Karachi Stock Exchange non-Nancial Listed Firms. MPRA Paper no. 37342, University of Munich.

Al-Ajmi, J., \& Hussain, H. A. (2011). Corporate Dividends Decisions: Evidence from Saudi Arabia. The Journal of Risk Finance, 12(1), 41-56. http://dx.doi.org/10.1108/15265941111100067

Al-Kuwari, D. (2009). Determinants of the Dividend Policy in Emerging Stock Exchanges: The Case of GCC Countries. Global Economy and Finance Journal, 2(2), 38-63.

Alli, K. L., Khan, A. Q., \& Ramirez, G. G. (1993). Determinants of Corporate Dividend Policy: A Factorial Analysis. Financial Review, 28(4), 523-547. http://dx.doi.org/10.1111/j.1540-6288.1993.tb01361.x

Al-Malkawi, H. A. N. (2007). Determinants of Corporate Dividend Policy in Jordan: An Application of the Tobit Model. Journal of Economic and Administrative Sciences, 23(2), 44-70. http://dx.doi.org/10.1108/10264116200700007

Al-Malkawi, H. A. N. (2008). Factors Influencing Corporate Dividend Decision: Evidence from Jordanian Panel Data. International Journal of Business and Management, 13(2), 178-195.

Al-Malkawi, H. A. N., Rafferty, M., \& Pillai, R. (2010). Dividend Policy: A Review of Theories and Empirical Evidence. International Bulletin of Business Administration, 9, 171-200.

Amidu, M., \& Abor, J. (2006). Determinants of Dividend Payout Ratios in Ghana. The Journal of Risk Finance, 7(2), 136-145. http://dx.doi.org/10.1108/15265940610648580

Antonios, A. (2010). Stock Market and Economic Growth: An Empirical Analysis for Germany. Business and Economics Journal, BEJ-1, 1-12.

Arellano, M., \& Bond, S. (1991). Some Tests of Specification for Panel Data: Monte Carlo Evidence and an Application to Employment Equations. The Review of Economic Studies, 58(2), 277-297. http://dx.doi.org/10.2307/2297968

Baker, H. K., Veit, E. T., \& Powell, G. E (2001). Factors Influencing Dividend Policy Decisions of Nasdaq 
Firms. The Financial Review, 38, 19-38. http://dx.doi.org/10.1111/j.1540-6288.2001.tb00018.x

Baker, M., \& Wurgler, J. (2004). A Catering Theory of Dividends. The Journal of Finance, LIX(3), 1125-1165. http://dx.doi.org/10.1111/j.1540-6261.2004.00658.x

Baskin, J. (1987). Corporate Liquidity in Games of Monopoly Power. The Review of Economics and Statistics, 69(2), 312-319. http://dx.doi.org/10.2307/1927239

Brealey, R., \& Myers, S. (2005). Principles of Corporate Finance (8th ed.). London: McGraw-Hill.

Chazi, A., Terra, P. R. S., \& Zanella, F. C. (2010). Theory versus Practice: Perspectives of Middle-Eastern $\begin{array}{lllll}\text { Financial Managers. } & \text { European }\end{array}$ http://dx.doi.org/10.11087/09555431011023524

Crutchley, C. E., \& Hansen, R. S. (1989). A Test of the Agency Theory of Managerial Ownership, Corporate Leverage, and Corporate Dividends. Financial Management, 18(4), 36-46. http://dx.doi.org/10.2307/3665795

Denis, D. J., \& Osobov, I. (2008). Why Do Firms Pay Dividends? International Evidence on the Determinants of $\begin{array}{lllll}\text { Dividend Policy. Journal of Financial Economics, } & \text { 89(1), }\end{array}$ http://dx.doi.org/10.1016/j.jfineco.2007.06.006

Dhanani, A. (2005). Corporate Dividend Policy: The Views of British Financial Managers. Journal of Business Finance \& Accounting, 32(7-8), 1625-1672. http://dx.doi.org/10.1111/j.0306-686X.2005.00643.x

Dickens, R. N., Casey, K. M., \& Newman, J. A. (2002). Bank Dividend Policy: Explanatory Factors. Quarterly Journal of Business and Economics, 41(1-2), 3-12.

Easterbrook, F. H. (1984). Two Agency-Cost Explanations of Dividends. The American Economic Review, 74(4), 650-659.

Evbayowieru, A. D. (2011). Dividend is Relevant: A Restatement. African Research Review: An International Multidisciplinary Journal, 5(4), 60-72.

Faccio, M., \& Lang, L. H. P. (2002). The Ultimate Ownership of Western European Corporations. Journal of Financial Economics, 65(3), 365-395. http://dx.doi.org/10.1016/S0304-405X(02)00146-0

Fama, E. F., \& French, K. R. (2001). Disappearing Dividends: Changing Firm Characteristics or Lower Propensity to Pay? Journal of Financial Economics, 60(1), 3-43. http://dx.doi.org/10.1016/S0304-405X(01)00038-1

Fama, E. F., \& French, K. R. (2002). Testing Trade-Off and Pecking Order Predictions about Dividends and Debt. Review of Financial Studies, 15(1), 1-33. http://dx.doi.org/10.1093/rfs/15.1.1

Fisher, G. R. (1961). Some Factors Influencing Share Prices. Economic Journal, 71(281), 121-141. http://dx.doi.org/10.2307/2228227

Frankfurter, G. M., \& Wood, B. G. (2002). Dividend Policy Theories and their Empirical Tests. International Review of Financial Analysis, 11(2), 111-138. http://dx.doi.org/10.1016/S1057-5219(02)00071-6

Gonzalez, V. M., \& Gonzalez, F. (2012). Firm Size and Capital Structure: Evidence using Dynamic Panel Data. Applied Economics, 44(36), 4745-4754. http://dx.doi.org/10.1080/00036846.2011.595690

Gordon, M. J., \& Shapiro, E. (1956). Capital Equipment Analysis: The Required Rate of Profit. Management Science Journal, 3(1), 102-110. http://dx.doi.org/10.1287/mnsc.3.1.102

Gul, F. A., \& Kealey, B. T. (1999). Chaebol, Investment Opportunity Set and Corporate Debt and Dividend Policies of Korean Companies. Review of Quantitative Finance and Accounting, 13(4), 401-416. http://dx.doi.org/10.1023/A:1008397808221

Jensen, G. R., Solberg, D. P., \& Zorn, T. S. (1992). Simultaneous Determination of Insider Ownership, Debt, and Dividend Policies. The Journal of Financial and Quantitative Analysis, 27(2), 247-263. http://dx.doi.org/10.2307/2331370

Jensen, M. C. (1986). Agency Costs of Free Cash Flow, Corporate Finance, and Takeovers. American Economic Review, 76(2), 323-329.

Jensen, M. C., \& Meckling, W. H. (1976). Theory of the Firm: Managerial Behavior, Agency Costs and Ownership Structure. Journal of Financial Economics, 3(4), 305-360. http://dx.doi.org/10.1016/0304-405X(76)90026-X 
Khan, M., \& Sendahji, A. (2000). Financial Development and Economic Growth: An Overview. Working Paper no. WP/00/209. International monetary fund, Washington, DC. http://dx.doi.org/10.5089/9781451874747.001

Kim, H., \& Gu, Z. (2009). Financial Features of Dividend-Paying Firms in the Hospitality Industry: A Logistic Regression Analysis. International Journal of Hospitality Management, 28(3), 359-366. http://dx.doi.org/10.1016/j.ijhm.2008.12.003

La Porta, R., Lopez-De-Silanes, F., Shleifer, A., \& Vishny, R. (2000). Investor Protection and Corporate $\begin{array}{lllll}\text { Governance. Journal of } & \text { Financial }\end{array}$ http://dx.doi.org/10.1016/S0304-405X(00)00065-9

Levine, R., \& Zervos, S. (1998). Stock Markets, Banks, and Economic Growth. The American Economic Review, 88(3), 537-558.

Lintner, J. (1956). Distribution of Incomes of Corporations among Dividends, Retained Earnings, and Taxes. The American Economic Review, 46(2), 97-113.

Lloyd, W. P., Jahera, J. S., \& Page, D. E. (1985). Agency Costs and Dividend Payout Ratios. Quarterly Journal of Business and Economics, 24(3), 19-29. http://dx.doi.org/10.1111/j.1540-6288.1985.tb00256.x

Lopez-Iturriage, F. J., \& Crisostomo, V. L. (2010). Do Leverage, Dividend Payout, and Ownership Concentration Influence Firms' Value Creation? An Anaysis of Brazilian Firms. Emerging Markets Finance \& Trade, 46(3), 80-94. http://dx.doi.org/10.2753/REE1540-496X.460306

Manos. (2001). Capital Structure and Dividend Policy: Evidence from Emerging Markets. PhD Thesis, University of Birmingham.

Miller, H. M., \& Rock, K. (1985). Dividend Policy under Asymmetric Information. Journal of Finance, 40(4), 1031-1051. http://dx.doi.org/10.1111/j.1540-6261.1985.tb02362.x

Miller, M. H., \& Modigliani, F. (1961). Dividend Policy, Growth, and the Valuation of Shares. The Journal of Business, 34(4), 411-433. http://dx.doi.org/10.1086/294442

Myers, S. C., \& Majluf, N. S. (1984). Corporate Financing and Investment Decisions when Firms have Information that Investors Do Not Have. Journal of Financial Economics, 13(2), 187-221. http://dx.doi.org/10.1016/0304-405X(84)90023-0

Naceur, S., Goaied, M., \& Belanes, A. (2006). On the Determinants and Dynamics of Dividend Policy. International Review of Finance, 6(1-2), 1-23. http://dx.doi.org/10.1111/j.1468-2443.2007.00057.x

Pagano, M. (1993). Financial Markets and Growth: An Overview. European Economic Review, 37(2-3), 613-622. http://dx.doi.org/10.1016/0014-2921(93)90051-B

Peyton, K., \& Belasen, A. R. (2012). Corruption in Emerging and Developing Economies: Evidence from a Pooled Cross-Section. Emerging market Finance \& Trade, 48(2), 29-43 http://dx.doi.org/10.2753/REE1540-496X480202

Reddy, Y. S., \& Rath, S. (2005). Disappearing Dividends in Emerging Markets? Evidence from India. Emerging Markets Finance \& Trade, 41(6), 58-82. http://dx.doi.org/10.1080/1540-496X.2005.11052626

Rozeff, M. S. (1982). Growth, Beta and Agency Costs as Determinants of Dividend Payout Ratios. Journal of Financial Research, 5(3), 249-259. http://dx.doi.org/10.1111/j.1475-6803.1982.tb00299.x

Turen, S., \& Salman, S. Y. H. (2012). What Really Determines the Dividend Policy in Financial Institutions: A Case of Bahrain. Middle Eastern Finance and Economics, (18), 56-66.

Wiwattanakantang, Y. (1999). An Empirical Study on the Determinants of the Capital Structure of Thai Firms. Pacific-Basin Finance Journal, 7(3-4), 371-403. http://dx.doi.org/10.1016/S0927-538X(99)00007-4

Yartey, C. A. (2009). The Stock Market and the Financing of Corporate Growth in Africa: The Case of Ghana. Emerging Markets Finance \& Trade, 45(4), 53-68. http://dx.doi.org/10.2753/REE1540-496X450404

\section{Copyrights}

Copyright for this article is retained by the author(s), with first publication rights granted to the journal.

This is an open-access article distributed under the terms and conditions of the Creative Commons Attribution license (http://creativecommons.org/licenses/by/3.0/). 